\title{
Faktor-Faktor Yang Mempengaruhi Kebijakan Hutang Pada Perusahaan Sektor Miscellaneous Industry
}

\author{
Tri Nurdyastuti ${ }^{1}$, Dibyo Iskandar $^{2}$, Suroto $^{3}$ \\ 1,2,3STIE-Adi Unggul Bhirawa Surakarta \\ tri.nurdyastuti@stie-aub.ac.id ${ }^{1}$
}

\begin{abstract}
Abstrak. Sektor miscellaneous industry memberikan kontribusi besar terhadap pertumbuhan ekonomi. Ekspor produk terus meningkat setiap tahunnya di pasar internasional namun terdapat fenomena dimana rata-rata debt to asset ratio (DAR) mengalami penurunan setiap tahunnya. Penelitian ini berfokus pada kebijakan hutang yang diproksikan dengan debt to asset ratio (DAR). Tujuan penelitian ini adalah menganalisis dan membuktikan secara empiris pengaruh signifikansi Kepemilikan Institusional, Kebijakan Dividen, dan Profitabilitas terhadap Kebijakan hutang. Populasi yang digunakan dalam penelitian ini adalah seluruh perusahaan Sektor Miscellaneous Industry yang terdaftar di Bursa efek Indonesia tahun 2016 -2019. Teknik pemilihan sampel menggunakan purposive sampling. Metode analisis yang digunakan adalah analisis regresi linier berganda. Berdasarkan hasil pengujian menunjukan bahwa Kepemilikan institusional berpengaruh negatif dan signifikan terhadap kebijakan hutang. Kebijakan dividen berpengaruh negatif dan signifikan terhadap kebijakan hutang. Profitabilitas berpengaruh positif dan signifikan terhadap kebijakan hutang. Nilai R Square sebesar 61,3\% yang artinya kebijakan hutang mampu dijelaskan oleh Kepemilikan Institusional, Kebijakan Dividen, dan Profitabilitas sebesar 61,3\% sedangkan sisanya 38,7\% dijelaskan oleh variabel lain
\end{abstract}

Kata kunci : Kepemilikan Institusional, Kebijakan Dividen, Profitabilitas, Kebijakan hutang.

\section{Pendahuluan}

Saham merupakan penyertaan modal seseorang atau badan usaha dalam suatu perseroaan terbatas dengan memperoleh keuntungan berupa deviden dan capital gain, investor selain mempunyai keuntungan juga memiliki risiko ketika berinvestasi saham yaitu risiko capital loss dan risiko likuidasi (www.idx.co.id). Saham di BEI diklasifikasikan menjadi sembilan sektor. Sektor miscellaneous industry merupakan salah satu sektor industri yang terdaftar di Bursa Efek Indonesia (BEI) yang mengelola bahan baku menjadi barang setengah jadi atau barang jadi. Sektor miscellaneous industry diklasifikasikan kembali menjadi sub sektor Machinery And Heavy Equipment, Automotive and Components, Textile, Garment, Footwear, Cable Electronics (www.idx.co.id)

Sektor miscellaneous industry memberikan kontribusi besar terhadap pertumbuhan ekonomi. Ekspor produk terus meningkat setiap tahunnya di pasar internasional (http:// m.detik.com). Meningkatnya nilai ekspor akan menaikan laba perusahaan. Apabila laba perusahaan tinggi maka perusahaan cenderung mengurangi pendanaan dari eksternal berupa hutang.

15 | Jurnal Buana Akuntansi 
Selain itu, perusahaan juga akan meningkatkan kemakmuran pemilik atau pemegang saham, dimana sering kali terjadi konflik antara pemegang saham institusional dengan manajer. Terdapat alternatif untuk mengurangi konflik tersebut yaitu dengan meningkatkan deviden payout ratio.

Penelitian ini berfokus pada kebijakan hutang yang ada di perusahaan sektor miscellaneous industry karena terdapat fenomena dimana rata-rata debt to asset ratio (DAR) mengalami penurunan setiap tahunnya. Pada tahun 2016 rata-rata DAR sebesar 93,34\%. Pada tahun 2017 mengalami penurunan menjadi 90,86\%. Pada tahun 2018 mengalami penurunan kembali menjadi $78,26 \%$.

Kondisi perekonomian saat ini yang telah memasuki era Masyarakat Ekonomi Asean (MEA) perusahaan dituntut untuk mampu bersaing dengan perusahaan-perusahaan asing yang masuk ke Indonesia. Persaingan tersebut membuat setiap perusahaan semakin meningkatkan kinerjanya guna mencapai tujuan perusahaan semaksimal mungkin. Perusahaan memiliki tujuan utama yaitu meningkatkan nilai perusahaan melalui peningkatan kemakmuran pemilik atau pemegang saham.

Pemilik modal menyerahkan pengelolaan perusahaan kepada manajer untuk mencapai tujuan utama perusahaan. Manajer bertanggung jawab terhadap keputusan alokasi dana. Seringkali manajer mempunyai tujuan lain yang bertentangan dengan tujuan utama. Maka timbulah konflik antara manajer dan pemegang saham yang biasa disebut konflik keagenan.

Konflik ini dapat diminimumkan dengan mekanisme pengawasan dan biaya yang timbul akibat dari mekanisme pengawasan yang disebut agency cost. Agency cost meliputi biaya untuk memonitori tindakan manajer, mencegah tingkah laku manajer yang tidak sesuai dengan tujuan perusahaan dan peluang yang hilang akibat pembatasan yang dilakukan pemegang saham terhadap manajer. Terdapat alternatif untuk mengurangi agency cost yaitu meningkatkan kepemilikan saham perusahaan, mekanisme pengawasan dalam perusahaan, meningkatkan deviden payout rasio, meningkatkan pendanaan dengan hutang.

Kebanyakan perusahaan memilih pendanaan hutang dikarenakan dengan menggunakan hutang operasi perusahaan lebih menghemat pajak atas laba perusahaan dan dapat meningkatkan nilai perusahaan. Perusahaan yang menggunakan hutang akan dipercaya karena telah memiliki kemampuan dan prospek yang cerah serta mendapatkan kepercayaan dari investor. Namun penggunaan hutang dapat meningkatkan risiko perusahaan, karena jika tidak mampu melunasi kembali hutang tersebut maka perusahaan akan terancam likuiditasnya.

Kebijakan hutang merupakan keputusan yang sangat penting dalam perusahaan, dimana kebijakan hutang merupakan salah satu bagian dari kebijakan pendanaan perusahaan. Kebijakan hutang adalah kebijakan yang diambil pihak manajemen dalam rangka memperoleh sumber daya pembiayaan bagi perusahaan sehingga dapat digunakan untuk membiayai aktivitas operasional perusahaan (Riyanto, 2011:98).

Menurut Nuraina (2012:116) Kepemilikan institusional adalah persentase saham perusahaan yang dimiliki oleh institusi atau lembaga (perusahaan asuransi, dana pensiunan atau perusahaan lain). Menurut Riyanti dan Lathifah (2016) kepemilikan institusional berpengaruh negatif dan signifikan terhadap kebijakan hutang, kepemilikan institusional dapat memonitor perilaku manajer secara efektif sehingga pihak manajemen akan bekerja untuk kepentingan para pemegang saham. Sebaliknya menurut Anindhita (2017). Kepemilikan institusional berpengaruh negatif tidak signifikan terhadap kebijakan hutang. 
Kebijakan deviden adalah keputusan apakah laba yang diperoleh perusahaan akan dibagikan kepada pemegang saham sebagai deviden atau akan ditahan dalam bentuk laba ditahan guna pembiayaan investasi dimasa datang (Sartono, 2012:281). Menurut Suryani dan Khafid (2015) Kebijakan deviden berpengaruh positif dan signifikan terhadap kebijakan hutang artinya semakin tinggi tingkat kebijakan deviden semakin tinggi kebijakan hutang perusahaan. Sebaliknya menurut Anindhita (2017) Kebijakan deviden berpengaruh negatif tidak signifikan terhadap kebijakan hutang. Perusahaan dengan devidend payout ratio yang tinggi menyukai pendanaan dengan modal sendiri.

Menurut Sartono (2010:122) Profitabilitas adalah kemampuan perusahaan memperoleh laba dalam hubungannya dengan penjualan, total aktiva maupun modal sendiri. Menurut Astuti (2014) Profitabilitas berpengaruh positif dan signifikan. Semakin tinggi profitabilitas yang dimiliki perusahaan, manajemen semakin yakin dengan kemampuannya untuk mencapai kinerja yang optimal sehingga mampu membayar hutang jangka panjangnya. Sebaliknya menurut Khusniyah dkk (2018) Profitabilitas berpengaruh positif tidak signifikan. Perusahaan yang mampu mendapatkan keuntungan yang tinggi (profitable) akan cenderung banyak memanfaatkan dana sendiri untuk keperluan investasi. Tingkat hutang perusahaan yang profitable dengan demikian akan semakin rendah.

Berdasarkan fenomena, teori serta penelitian terdahulu maka peneliti tertarik meneliti kembali dengan judul "Faktor-Faktor Yang Mempengaruhi Kebijakan Hutang Pada Perusahaan Sektor Miscellaneous Industry “

Tujuan penelitian ini adalah untuk menganalisis dan memberikan bukti empiris pengaruh signifikansi : Kepemilikan institusional terhadap kebijakan hutang, Kebijakan deviden terhadap kebijakan hutang, Profitabilitas terhadap kebijakan hutang.

\section{Tinjauan Pustaka}

\subsection{Teori-teori kebijakan hutang}

Beberapa teori kebijakan hutang (Sudana, 2011:156):

2.1.1. Trade of Theory yaitu keputusan perusahaan dalam memanfaatkan hutang demi kesimbangan antara efisensi pajak dan biaya kesulitan keuangan.

2.1.2. Pecking Order Theory yaitu manajer memilih pendanaan internal daripada pendanaan eksternal. Jika manajer membutuhkan dana dari eksternal, manajer lebih menyukai hutang

2.1.3. Signaling Theory menyatakan bahwa perusahaan yang menghasilkan laba cenderung meningkatkan hutangnya karena tambahan bunga yang dibayar diimbangi dengan laba sebelum pajak.

\subsection{Kebijakan Hutang}

Kebijakan hutang merupakan salah satu bagian dari kebijakan pendanaan perusahaan. Menurut Harmono (2011:137) Keputusan pendanaan oleh manajemen akan berpengaruh terhadap perusahaan yang terefleksi pada harga saham. Terdapat 2 rasio hutang yaitu Debt to asset ratio (DAR) dan Debt to equity ratio (DER). Menurut Kasmir (2011) Rasio DAR merupakan rasio hutang yang digunakan untuk mengukur seberapa besar aktiva perusahaan dibiayai oleh hutang atau seberapa besar hutang perusahaan berpengaruh terhadap pengelolaan aktiva. Rumus DAR sebagai berikut: 


\section{Buana Akuntansi}

TRI, DIBYO,\& SUROTO

Vol 6 No 1

ISSN 2528-1119

E-ISSN 2580-5452

$$
\text { DAR }=\frac{\text { Total Utang }}{\text { Total Aset }} \times 100 \%(\text { Kasmir, 2011) }
$$

Debt to equity ratio (DER) Menurut Kasmir (2011) Rasio DER merupakan rasio hutang yang digunakan untuk mengukur seberapa banyak penggunaan hutang sebagai pendanaannya. Rumus DER sebagai berikut:

$$
\mathrm{DER}=\frac{\text { Total Utang }}{\text { Total Ekuitas }} \times 100 \%(\text { Kasmir, 2011) }
$$

\subsection{Kepemilikan Institusional}

Kepemilikan institusional adalah persentase saham perusahaan yang dimiliki oleh institusi atau lembaga misalnya perusahaan asuransi, dana pensiunan, atau perusahaan lain (Nuraina, 2012:116). Kepemilikan institusional memiliki pengawasan yang lebih kuat dibandingkan pemegang saham lainnya sesui dengan teori keagenan dimana ketika terdapat banyak institusional investor artinya ada satu kontrol yang banyak dan kuat dari pihak institusional sehingga akan dapat dengan mudah untuk menjadi pemilik saham mayoritas. Rumus kepemilikan institusional sebagai berikut :

$$
\text { INST }=\frac{\text { Jumlah saham dimiliki institusi }}{\text { Jumlah saham yang beredar }} \times 100 \% \text { (Yuniati dkk, 2016) }
$$

\subsection{Kebijakan deviden}

Kebijakan deviden adalah keputusan apakah laba yang diperoleh perusahaan akan dibagikan kepada pemegang saham sebagai deviden atau akan ditahan dalam bentuk laba ditahan untuk pembiayaan investasi yang akan datang (Sartono, 2012:281). Kebijakan deviden diproksikan dengan dividend payout ratio (DPR). Rumus kebijakan deviden sebagai berikut:

$$
\mathrm{DPR}=\frac{\text { Devidend per share }}{\text { Earring per share }} \times 100 \% \text { (Indah ningrum dan Ratih,2009) }
$$

\subsection{Profitabilitas}

Menurut Sartono (2010:122) profitabilitas adalah kemampuan perusahaan memperoleh laba terkait dengan penjualan, total aktiva maupun modal sendiri. Menurut Sudana (2011:22) cara untuk mengukur profitabilitas perusahaan dengan Return On Equity (ROE) Rasio ini menunjukkan kemampuan perusahaan untuk menghasilkan laba setelah pajak dengan menggunakan modal sendiri yang dimiliki perusahaan.

$$
\mathrm{ROE}=\frac{\text { Laba setelah pajak }}{\text { Totalmodal sendiri }} \times 100 \%
$$

Kerangka pikir dibuat sebagai sarana memudahkan arah dalam penelitian. Berdasarkan uraian teori sebelumnya dapat digambarkan skema kerangka pemikiran sebagai berikut:

18 | Jurnal Buana Akuntansi 


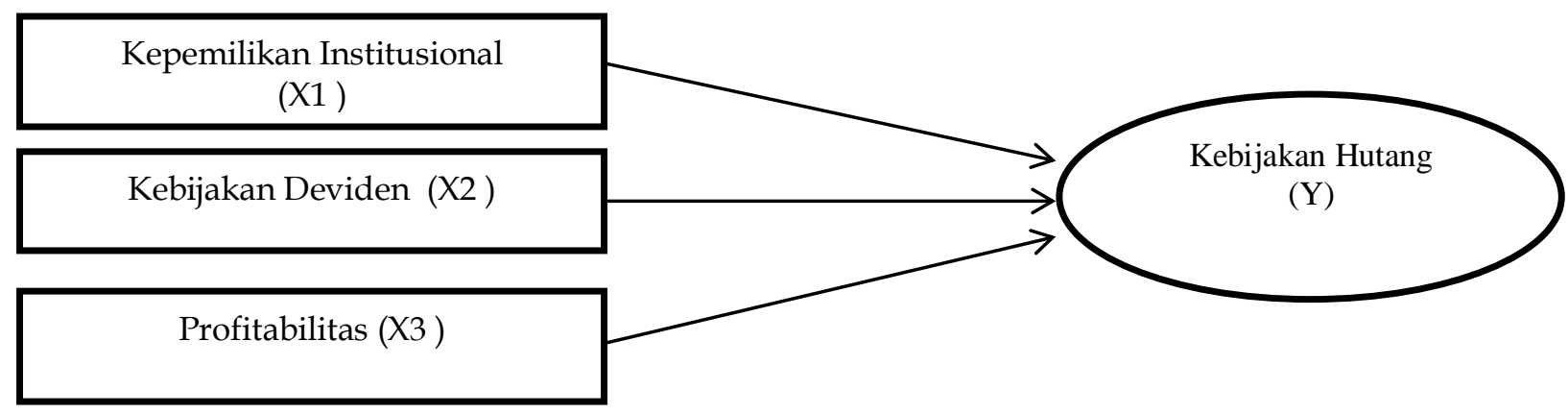

Gambar 2.1. Kerangka Pemikiran

Sumber : Riyanti dan Lathifah (2016), Suryani dan Khafid (2015), Anindhita (2017).

\section{Metodologi Penelitian}

Jenis data yang digunakan adalah data sekunder yang diakses melalui situs website www.idx.co.id. Teknik pengambilan sampel dengan purposiv sampling. Penelitian ini dilakukan pada perusahaan Sektor miscellaneous industry yang terdaftar di Bursa Efek Indonesia periode 2016-2019. Objek penelitian ini adalah laporan keuangan perusahaan Sektor miscellaneous industry yang terdaftar di Bursa Efek Indonesia tahun 2016-2019. Definisi Operasional Variabel disajikan dalam tabel 2.1.

Tabel 3.1. Definisi Operasional Variabel

\begin{tabular}{c|c|c|c|c}
\hline No & Variabel & Indikator & Skala & Sumber \\
\hline 1. & $\begin{array}{c}\text { Kebijakan } \\
\text { Hutang(Y) } \\
(\text { Kasmir, 2011) }\end{array}$ & DAR $=\frac{\text { Total Utang }}{\text { Total Aset }} \times 100 \%$ & Rasio & $\begin{array}{c}\text { Laporan } \\
\text { Keuangan }\end{array}$ \\
\hline 2. & $\begin{array}{c}\text { Kepemilikan } \\
\text { Institusional }\left(\mathrm{X}_{1}\right) \\
(\text { Yuniati dkk, 2016) }\end{array}$ & INST $=\frac{\text { Jumlah saham dimiliki institusi }}{\text { Jumlah saham yang beredar }}$ X 100\% & Rasio & $\begin{array}{c}\text { Laporan } \\
\text { Keuangan }\end{array}$ \\
\hline 3. & $\begin{array}{c}\text { Kebijakan } \\
\text { Deviden }\left(\mathrm{X}_{2}\right) \\
(\text { Indahningrum } \\
\text { dan Ratih, 2009) }\end{array}$ & DPR $=\frac{\text { Devidend per share }}{\text { Earning per share }} \mathrm{X} 100 \%$ & Rasio & Laporan \\
Keuangan
\end{tabular}

Populasi yang digunakan dalam penelitian ini adalah perusahaan Sektor miscellaneous industry yang terdaftar di Bursa Efek Indonesia tahun 2016-2019. Pengambilan sampel menggunakan teknik purposive sampling yang merupakan teknik pengambilan sampel dengan kriteria tertentu. Kriteria pengambilan sampel adalah sebagai berikut: 
Tabel 4.1. Proses Pemilihan Sampel

\begin{tabular}{c|l|c}
\hline No & \multicolumn{1}{|c|}{ KriteriaPengambilan Sampel } & Jumlah \\
\hline 1 & $\begin{array}{l}\text { Perusahaan Sektor miscellaneous industry yang } \\
\text { terdaftar di BEI tahun 2016-2019 }\end{array}$ & 51 \\
\hline 2 & $\begin{array}{l}\text { Perusahaan yang tidak mencantumkan sahamnya } \\
\text { dalam papan utama }\end{array}$ & $(27)$ \\
\hline 3 & $\begin{array}{l}\text { Perusahaan yang tidak yang mengeluarkan } \\
\text { saham lebih dari 4.000.000.000 lembar }\end{array}$ & $(3)$ \\
\hline 4 & $\begin{array}{l}\text { Perusahaan yang tidak menyajikan data } \\
\text { keuangan lengkap Sampel Penelitian }\end{array}$ & 10 \\
\hline \multicolumn{2}{c}{ Total Sampel Penelitian Selama 4 Tahun } \\
\hline
\end{tabular}

Sumber : Data BEI tahun 2020

Berdasarkan hasil dari pengambilan sampel menggunakan teknik purposive sampling terdapat 10 perusahaan yang layak untuk dijadikan sampel dengan jumlah tahun pengamatan 4 tahun. Total terdapat 40 data yang valid selama periode penelitian. Adapun daftar nama perusahaan sektor miscellaneous industry selama tahun 2016-2019 adalah sebagai berikut:

Tabel 4.2. Data Nama Perusahaan Yang Menjadi Sampel

\begin{tabular}{l|l|l} 
No. & $\begin{array}{c}\text { Kode } \\
\text { Perusahaan }\end{array}$ & \multicolumn{1}{c}{ Nama Perusahaan } \\
\hline 1 & ASII & Astra International Tbk. \\
\hline 2 & AUTO & Astra Otoparts Tbk. \\
\hline 3 & GMFI & Garuda Maintenance Facility Ae \\
\hline 4 & KBLI & KMI Wire \& Cable Tbk. \\
\hline 5 & MASA & Multistrada Arah Sarana Tbk. \\
\hline 6 & PTSN & Sat Nusapersada Tbk \\
\hline 7 & SMSM & Selamat Sempurna Tbk. \\
\hline 9 & SRIL & Sri Rejeki Isman Tbk. \\
\hline 10 & STAR & Buana Artha Anugerah Tbk. \\
\hline
\end{tabular}

Sumber: Data BEI tahun 2020

Metode analisis data menggunakan uji asumsi klasik, uji t, uji F, uji koefisien determinasi dan regresi linear berganda yang dirumuskan sebagai berikut:

Dimana:

$$
Y=a+\beta_{1} X_{1}+\beta_{2} X_{2}+\beta_{3} X_{3}+\varepsilon
$$

$$
\begin{aligned}
& \text { Y } \quad=\text { Kebijakan Hutang } \\
& \mathrm{X}_{1} \quad=\text { Kepemilikan institusional } \\
& \mathrm{X}_{2} \quad=\text { Kebijakan Deviden } \\
& \mathrm{X}_{3} \quad=\text { Profitabilitas }
\end{aligned}
$$

20 | Jurnal Buana Akuntansi 


\section{Buana Akuntansi}

TRI, DIBYO,\& SUROTO

Vol 6 No 1

ISSN 2528-1119

E-ISSN 2580-5452

$$
\begin{aligned}
& \beta_{1 . .} \beta_{3} \quad=\text { Koefisien Regresi } \\
& \text { a } \quad=\text { Konstanta } \\
& \text { E }=\text { Error }
\end{aligned}
$$

\section{Analisis dan Pembahasan}

4.1 Statistik Deskriptif

Statistik deskriptif variabel disajikan dalam tabel 4.3 berikut:

Tabel 4.3. Statistik Deskrptif

\begin{tabular}{l|r|r|r|r|r}
\hline & \multicolumn{1}{|c|}{$N$} & Minimum & Maximum & \multicolumn{1}{c|}{ Mean } & Std. Deviation \\
\hline Kepemilikan Institusional & 40 & $-16,39$ & 16,87 & 5,6305 & 6,62034 \\
Kebijakan Deviden & 40 & $-8,79$ & 23,25 & 6,1088 & 7,04981 \\
Profitabilitas & 40 & $-22,83$ & 30,81 & 10,8888 & 11,68341 \\
Kebijakan Hutang & 40 & 15,49 & 75,78 & 43,7248 & 17,05912 \\
Valid N (listwise) & 40 & & & & \\
\hline
\end{tabular}

Sumber: Data diolah 2020

Berdasarkan tabel di atas diketahui rata-rata Kepemilikan Institusional adalah 5,6305 dengan nilai standar deviasi sebesar 6,62034, nilai rata- rata Kebijakan Deviden sebesar 6,1088 dengan nilai standar deviasi 7,04981, nilai rata-rata Profitabilitas sebesar 10,8888 dengan nilai standar deviasi sebesar 11,68341 dan nilai rata-rata kebijakan hutang sebesar 43,7248 dengan standar deviasi sebesar 17,05912.

\subsection{Uji Asumsi Klasik}

Untuk menguji seberapa jauh pengaruh Kepemilikan Institusional ( $\left.\mathrm{X}_{1}\right)$, Kebijakan Deviden $\left(X_{2}\right)$, Profitabilitas $\left(X_{3}\right)$, dan terhadap kebijakan hutang $(Y)$. Maka peneliti menggunakan analisis data kuantitatif berupa regresi linier berganda.

\subsubsection{Uji Normalitas}

Hasil uji normalitas disajikan dalam tabel 4.4.

Tabel 4.4. Uji Normalitas

\begin{tabular}{ll|r}
\hline & & $\begin{array}{c}\text { Unstandardiz } \\
\text { ed Residual }\end{array}$ \\
\hline $\mathrm{N}$ & Mean & $\begin{array}{c}36 \\
\text { Normal Parameters a,b }\end{array}$ \\
& Std. Deviation &, 0000000 \\
Most Extreme & Absolute & 10,96119417 \\
Differences & Positive &, 142 \\
& Negative &, 099 \\
Kolmogorov-Smirnov Z & &,- 142 \\
Asymp. Sig. (2-tailed) & &, 854 \\
\hline Sumber: Data diolah 2020 &, 460 \\
\hline
\end{tabular}

Berdasarkan tabel di atas, nilai Asymp.Sig.(2-tailed) sebesar 0,460 lebih besar dari nilai signifikan 0,05. Sehingga dapat disimpulkan bahwa data tersebut berdistribusi secara normal.

\subsubsection{Uji Multikolinieritas}

Hasil uji Multikolinieritas disajikan dalam tabel 4.5. 
Tabel 4.5. Uji Multikolinieritas

\begin{tabular}{|c|c|c|c|c|c|c|c|c|}
\hline \multirow[b]{2}{*}{ Model } & & \multicolumn{2}{|c|}{$\begin{array}{c}\text { Unstandardized } \\
\text { Coefficients } \\
\end{array}$} & \multirow{2}{*}{$\begin{array}{c}\text { Standardized } \\
\text { Coefficients } \\
\text { Beta }\end{array}$} & \multirow[b]{2}{*}{ t } & \multirow[b]{2}{*}{ Sig. } & \multicolumn{2}{|c|}{ Collinearity Statistics } \\
\hline & & $\mathrm{B}$ & Std. Error & & & & Tolerance & VIF \\
\hline \multirow[t]{4}{*}{1} & (Constant) & 42,520 & 2,932 & & 14,501 &, 000 & & \\
\hline & Kepemilikan Institusional & $-28,475$ & 8,629 &,- 960 & $-3,300$ &, 002 & ,144 & 6,951 \\
\hline & Kebijakan Deviden & $-1,743$ &, 450 &,- 648 & $-3,871$ &, 001 & ,434 & 2,302 \\
\hline & Profitabilitas & 38,318 & 6,192 & 1,689 & 6,189 &, 000 & 163 & 6,124 \\
\hline
\end{tabular}

Sumber: Data diolah 2020

Berdasarkan tabel di atas, nilai tolerance Kepemilikan institusional 0,144 Kebijakan deviden 0,434 dan Profitabilitas 0,163 lebih besar dari 0,10 serta nilai VIF Kepemilikan istitusional 6,951 Kebijakan deviden 2,302 dan Profitabilitas 6,124 lebih kecil dari 10 sehingga dapat disimpulkan tidak terjadi multikolinieritas.

\subsubsection{Uji Heteroskedastisitas}

Hasil uji heteroskedastisitas disajikan dalam tabel 4.6.

Tabel 4.6 Uji Heteroskedastisitas

\begin{tabular}{ll|r|r|r|r|r}
\hline \multirow{2}{*}{ Model } & \multicolumn{2}{|c|}{$\begin{array}{c}\text { Unstandardized } \\
\text { Coefficients }\end{array}$} & \multicolumn{2}{c|}{$\begin{array}{c}\text { Standardized } \\
\text { Coefficients }\end{array}$} & \multicolumn{1}{c}{} \\
\cline { 2 - 5 } & \multicolumn{1}{c|}{ B } & \multicolumn{1}{c|}{ Std. Error } & \multicolumn{1}{c}{ Beta } & \multicolumn{1}{c}{ Sig. } \\
\hline 1 & (Constant) & 12,030 & 1,449 & & 8,302 &, 000 \\
& Kepemilikan Institusional & $-8,166$ & 4,264 &,- 751 & $-1,915$ &, 064 \\
& Kebijakan Deviden &,- 335 &, 223 &,- 340 & $-1,507$ &, 142 \\
& Profitabilitas & 5,210 & 3,060 &, 627 & 1,703 &, 098 \\
\hline
\end{tabular}

Sumber: Data diolah 2020

Berdasarkan di atas, nilai signifikansi $>0,05$, sehingga dapat disimpulkan bahwa dari pengujian ini tidak terjadi heteroskedastisitas.

\subsubsection{Uji Autokorelasi}

Hasil uji autokorelasi disajikan dalam tabel 4.7.

Tabel 4.7. Uji Autokorelasi

\begin{tabular}{l|r|r|r|r|r}
\hline Model & $\mathrm{R}$ & R Square & $\begin{array}{r}\text { Adjusted } \\
\text { R Square }\end{array}$ & $\begin{array}{r}\text { Std. Error of } \\
\text { the Estimate }\end{array}$ & $\begin{array}{c}\text { Durbin- } \\
\text { Watson }\end{array}$ \\
\hline 1 &, $781^{\mathrm{a}}$ &, 611 &, 574 & 11,46349 &, 968 \\
\hline
\end{tabular}

Sumber: Data diolah 2020

Berdasarkan di atas, nilai Durbin-Watson terletak diantara -2 dan 2 yaitu $-2<0,968<2$ dapat disimpulkan bahwa dari pengujian ini bebas dari auto korelasi antar variabel.

\subsection{Uji Hipotesis}

Hasil dari uji analisis regresi linier berganda disajikan dalam tabel 4.8.

Tabel 4.8. Regresi Linier Berganda

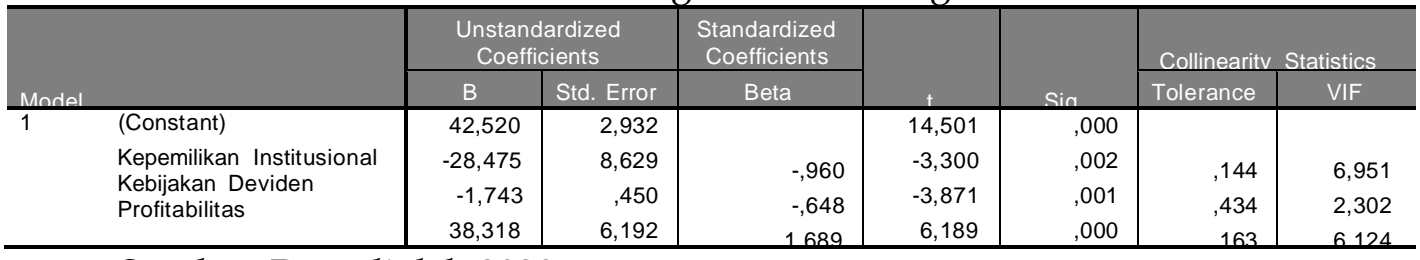

Sumber: Data diolah 2020 
Persamaan dari uji linier berganda sebagai berikut :

$$
\begin{aligned}
Y= & \alpha+\beta_{1} X_{1}+\beta_{2} X_{2}+\beta_{3} X_{3}+\mathbf{e} \\
Y= & 42,520-28,475 X_{1}-1,743 X_{2}+38,318 X_{3}+e \\
& (0,000) \quad(0,002) \quad(0,001) \quad(0,000)
\end{aligned}
$$

\subsubsection{Uji t}

Berdasarkan tabel 4.8. dapat disimpulkan bahwa Kepemilikan institusional, Kebijakan deviden dan Profitabilitas berpengaruh signifikan terhadap kebijakan hutang, hal ini dibuktikan dengan nilai signifikansi dari masing-masing variabel $<0,05$.

\subsubsection{Uji F}

\begin{tabular}{|c|c|c|c|c|c|c|}
\hline Model & & $\begin{array}{l}\text { Sum of } \\
\text { Squares } \\
\end{array}$ & df & Mean Square & $\mathrm{F}$ & Sig. \\
\hline \multirow[t]{3}{*}{1} & Regression & 6597,299 & 3 & 2199,100 & 16,734 &, $000^{\mathrm{a}}$ \\
\hline & Residual & 4205,172 & 32 & 131,412 & & \\
\hline & Total & 10802,472 & 35 & & & \\
\hline
\end{tabular}

Hasil uji t disajikan dalam tabel 4.9. sebagai berikut:

Tabel 4.9. Hasil uji F

Sumber: Data diolah 2020

Berdasarkan tabel di atas, dapat disimpulkan nilai sig 0,000 lebih kecil dari nilai signifikansi 0,05 sehingga Kepemilikan Institusional $\left(\mathrm{X}_{1}\right)$, Kebijakan Deviden $\left(\mathrm{X}_{2}\right)$, dan Profitabilitas $\left(\mathrm{X}_{3}\right)$ secara bersama-sama berpengaruh signifikan terhadap kebijakan hutang.

\subsubsection{Uji Koefisien Determinasi $\left(\mathbf{R}^{2}\right)$}

Hasil Uji Koefisien Determinasi $\left(\mathbf{R}^{2}\right)$ disajikan dalam tabel 4.10. Tabel 4.10. Uji Koefisien Determinasi $\left(\mathrm{R}^{2}\right)$

\begin{tabular}{l|r|r|r|r|r}
\hline Model & \multicolumn{1}{|c|}{$\mathrm{R}$} & R Square & $\begin{array}{c}\text { Adjusted } \\
\text { R Square }\end{array}$ & $\begin{array}{r}\text { Std. Error of } \\
\text { the Estimate }\end{array}$ & $\begin{array}{c}\text { Durbin- } \\
\text { Watson }\end{array}$ \\
\hline 1 &, $783^{\mathrm{a}}$ &, 613 &, 576 & 11,437166 &, 967 \\
\hline
\end{tabular}

Sumber: Data diolah 2020

Berdasarkan tabel di atas, uji koefisien determinasi menunjukkan nilai Adjusted $\mathrm{R}^{2}$ sebesar 0,613 atau 61,3\% maka dapat disimpulkan bahwa pengaruh variabel independen yaitu kepemilikan institusional, kebijakan deviden dan profitabilitas terhadap varibel dependen yaitu kebijakan hutang sebesar 61,3\% sisanya 38,7\% dipengaruhi oleh variabel lain.

\subsection{Pembahasan}

Pembahasan akan menjelaskan mengenai hasil pengujian hubungan antar variabel yang dihipotesiskan antara lain Kepemilikan Institusional $\left(\mathrm{X}_{1}\right)$, Kebijakan Deviden $\left(\mathrm{X}_{2}\right)$, Profitabilitas $\left(X_{3}\right)$, dan terhadap kebijakan hutang $(Y)$. Berikut penjelasan dari masing-masing variabel yang dihipotesiskan:

1. Pengaruh kepemilikan institusional terhadap kebijakan hutang

Koefisien regresi kepemilikan institusional adalah -28,475 dengan nilai signifikansi sebesar 0,002 . Hal ini berarti kepemilikan institusional berpengaruh negatif dan signifikan terhadap kebijakan hutang, sehingga H1 diterima. Penelitian ini mendukung penelitian yang 
dilakukan Riyanti dan Lathifah (2016) bahwa kepemilikan institusional berpengaruh negatif dan signifikan terhadap kebijakan hutang. Penelitian ini menunjukan apabila suatu perusahaan dikuasai oleh institusional investor yang mengakibatkan munculnya kontrol ketat terhadap manajer, sehingga pendanaan perusahaan dari eksternal berupa hutang akan ditekan.

2. Pengaruh kebijakan deviden terhadap kebijakan hutang

Koefisien regresi kepemilikan institusional adalah -28,475 dengan nilai signifikansi sebesar 0,001 . Hal ini berarti kebijakan deviden berpengaruh negatif dan signifikan terhadap kebijakan hutang, sehingga H2 diterima. Penelitian ini mendukung penelitian yang dilakukan Suryani dan Khafid (2015) bahwa kebijakan deviden berpengaruh positif dan signifikan terhadap kebijakan hutang. Penelitian ini menunjukan apabila perusahaan meningkatkan pembayaran deviden kepada para investor maka laba ditahan semakin kecil untuk memenuhi kebutuhan perusahaan, sehingga penggunaan hutang oleh perusahaan semakin meningkat.Sebaliknya apabila perusahaan menekan pembayaran deviden kepada para investor maka laba ditahan semakin meningkat untuk memenuhi kebutuhan perusahaan, sehingga penggunaan hutang oleh perusahaan menurun.

3. Pengaruh profitabilitas terhadap kebijakan hutang

Koefisien regresi profitabilitas adalah 38,318 dengan nilai signifikansi sebesar 0,000. Hal ini berarti profitabilitas berpengaruh positif dan signifikan terhadap kebijakan hutang, sehingga H3 diterima. Penelitian ini mendukung penelitian yang dilakukan oleh Astuti (2014) bahwa profitabilitas berpengaruh positif dan signifikan. Penelitian ini menunjukan terjadi anomali karena nilai profitabilitas dalam penelitian ini adalah positif. Hasil ini menunjukan laba tidak digunakan untuk kegiatan operasional perusahaan dan cenderung disimpan sebagai laba ditahan untuk pembiayaan investasi di masa yang akan datang, sehingga pendanaan operasional perusahaan berupa hutang meningkat.

\section{Kesimpulan, Keterbatasan, dan Saran}

Kesimpulan dari penelitian ini adalah kepemilikan institusional berpengaruh negatif dan signifikan terhadap kebijakan hutang; kebijakan deviden berpengaruh negatif dan signifikan terhadap kebijakan hutang; profitabilitas berpengaruh positif dan signifikan terhadap kebijakan hutang; nilai $R^{2}$ sebesar 0,613 atau $61,3 \%$. Menunjukan bahwa kemampuan menjelaskan ketiga variabel bebas terhadap kebijakan hutang sebesar $61,3 \%$.

Keterbatasan dalam penelitian ini antara lain penelitian ini hanya meneliti 10 perusahaan sebagai sampel penelitian, sehingga belum dapat dianggap menggeneralisasi seluruh sampel perusahaan Sektor miscellaneous industry yang terdaftar di BEI secara keseluruhan.

Pada penelitian berikutnya diharapkan dapat dilakukan kajian lebih lanjut terhadap beberapa variabel lainmisalnya ukuran perusahaan, current ratio, harga saham dan lain-lain.

\section{Daftar Pustaka}

Anindhita, Niken (2017). Pengaruh Kepemilikan Saham Institusi, Kepemilikan Saham Publik, Kebijakan Dividen, Struktur Aset, Dan Profitabilitas Terhadap Kebijakan Hutang Perusahaan Manufaktur Di Bursa Efek Indonesia Tahun 2012-2014. Jurnal Akuntansi. Vol. 1 No. 2 
Astuti, Elly (2014). Pengaruh Kepemilikan Institusional, Profitabilitas, Ukuran Perusahaan Terhadap Kebijakan Hutang Perusahaan Di Indonesia. Jurnal Akuntansi Dan Pajak. Vol. 15 No. 02 Fahmi, Irham. 2014. Pengantar Manajemen Keuangan. Bandung: Alfabeta

Ghozali, Imam. 2013. Aplikasi Analisis Multivariate dengan Program IBM SPSS 21 Update PLS Regresi. Semarang: Badan Penerbit Universitas Diponegoro.

Harmono. 2011. Manajemen Keuangan Berbasis Balanced Scorecard Pendekatan Teori, Kasus, dan Riset Bisnis (Edisi 1). Jakarta : Bumi Aksara

http://m.detik.com/news/adv-nhl-detikcom/d-4439261/industri-makanan-jadi-salah-satu sektor-tingkatan-nilai-investasi $\backslash$

Indahningrum, R.P dan Handayani, Ratih. 2009, Pengaruh Kepemilikan manajerial, Kepemilikan Institusional, Dividen,Pertumbuhan Perusahaan, Free Cash Flow, dan Profitabilitas Terhadap Kebijakan Hutang Perusahaan. Jurnal Bisnis dan Akuntansi. Vol.11, No.3, Desember, hal. 189-207

Kasmir, 2011, “Analisis Laporan Keuangan”, Raja Grafindo Persada: Jakarta.

Khusniyah, D.N., Maslichah, Junaidi (2018). Pengaruh Kepemilikan Manajerial, Kepemilikan Institusional, Kebijakan Dividen, Profitabilitas Terhadap Kebijakan Hutang (Studi Empiris Pada Perusahaan Manufaktur Yang Terdaftar Di Bursa Efek Indonesia Periode 2012-2016). Jurnal Akuntansi, Vol. 07 No. 11.

Murni, Sri dan Andriana., 2007, Pengaruh Insider Ownership, Institutional Investor, Dividend Payments, dan Firm Growth terhadap KebijakanHutang Perusahaan (Studi Kasus pada Perusahaan Manufaktur yang Terdaftar di Bursa Efek Jakarta). Jurnal Akuntansi dan Bisnis. Vol.7, No.1, Februari, Hlm.15-24

Nuraina, Elva. 2012. Pengaruh Kepemilikan Institusional dan Ukuran Perusahaan Terhadap Kebijakan Hutang dan Nilai Perusahaan. Jurnal Bisnis dan Ekonomi, September 2012, Hal 110-125 Rajagukguk, L., Widyastuty, E., Pakpahan, Y. (2017). Analisis Pengaruh Kebijakan Deviden, Struktur Aset, dan Pertumbuhan Penjualan Terhadap Kebijakan Utang Pada Perusahaan Manufaktur Yang Terdaftar di Bursa Efek Indonesia Tahun 2011-2015. Jurnal Akuntansi, Vol.17, No. 1, Hal. 1-14.

Riyanti dan Ifah Latifah. (2016). Pengaruh Kepemilikan Manajerial, Kepemilikan Institusional, Kebijakan Deviden Terhadap Kebijakan Hutang (Studi Kasus Pada Perusahaan Manufaktur Yang Terdaftar Di BEI Periode 2011-2013). Jurnal Akuntansi. Vol. 4 No.1.

Riyanto, Bambang. 2011. Dasar-Dasar Pembelanjaan Perusahaan. Edisi Keempat, Yogyakarta: BPFE.

Sartono, Agus. 2012. "Manajemen Keuangan Teori dan Aplikasi." Edisi Keempat, Yogyakarta: BPFE.

Solikin, Ikin, Mimin. W, Sofie D.L. 2013. Pengaruh struktur kepemilikan, struktur modal, dan ukuran perusahaan terhadap nilai perusahaan pada perusahaan sektor pertambangan yang terdaftar di BEI. Jurnal Riset Akuntansi dan Keuangan. Vol.3 No.2. 774-790 Universitas Pendidikan Indonesia

Sudana, I Made. 2011. Manajemen Keuangan Perusahaan. Erlangga, Jakarta.

Sugiyono. (2016). Metode Penelitian Kuantitatif, Kualitatif dan RED. Bandung: Alfabeta

Suryani, Ade Dwi dan Muhammad Khafid. 2015. Pengaruh Free Cash Flow, Pertumbuhan Perusahaan, Kebijakan Dividen, dan Ukuran Perusahaan Terhadap Kebijakan Hutang 


\section{Buana Akuntansi}

TRI, DIBYO,\& SUROTO

Vol 6 No 1

ISSN 2528-1119

E-ISSN 2580-5452

Pada Perusahaan Manufaktur di Bursa Efek Indonesia Tahun 2013. Jurnal Akuntansi, Keuangan, danPerbankan. Vol. 4 No. 1.

Susanto, Yulius Kurnia. (2011). Kepemilikan Saham, Kebijakan Dividen, Karakteristik Perusahaan, Risiko Sistimatik, Set Peluang Investasi danKebijakan Hutang. Jurnal Bisnis dan Akuntansi, 13 (3).

Yuniati, Mei, Kharis Raharjo, Abrar Oemar. 2016. Pengaruh kebijakan Deviden,kebijakan hutang, pofitabilitas dan struktur kepemilikan terhadan nilai perusahaan pada perusahaan manufaktur yang terdaftar di BEI 20092014. Journal of Accounting. Vol.2 No.2. Universitas Pandanaran Semarang. 